\title{
Progesterone-responsive vaginal leiomyoma and hyperprogesteronemia due to ovarian luteoma in an older bitch
}

\author{
L. Ferré-Dolcet* (D), S. Romagnoli, T. Banzato, L. Cavicchioli, R. Di Maggio, A. Cattai, M. Berlanda, M. Schrank and
}

A. Mollo

\begin{abstract}
Background: This is the first report about a vaginal leiomyoma concomitant with an ovarian luteoma in a bitch.

Case presentation: A 11-year-old intact female Labrador retriever was referred because of anuria, constipation and protrusion of a vaginal mass through the vulvar commissure. The bitch had high serum progesterone concentration $(4.94 \mathrm{ng} / \mathrm{ml})$. Because of the possibility of progesterone responsiveness causing further increase of the vaginal mass and since the bitch was a poor surgical candidate a $10 \mathrm{mg} / \mathrm{kg}$ aglepristone treatment was started SC on referral day 1. A computerized tomography showed a $12.7 \times 6.5 \times 8.3 \mathrm{~cm}$ mass causing urethral and rectal compression, ureteral dilation and hydronephrosis. A vaginal leiomyoma was diagnosed on histology. As serum progesterone concentration kept increasing despite aglepristone treatment, a $0.02 \mathrm{ng} / \mathrm{mL}$ twice daily IM alfaprostol treatment was started on day 18. As neither treatment showed remission of clinical signs or luteolysis, ovariohysterectomy was performed on referral day 35. Multiple corpora lutea were found on both ovaries. On histology a luteoma was diagnosed on the left ovary. P4 levels were undetectable 7 days after surgery. Recovery was uneventful and 12 weeks after surgery tomography showed a reduction of $86.7 \%$ of the vaginal mass. The bitch has been in good health and able to urinate without any complication ever since.
\end{abstract}

Conclusions: This case demonstrates the importance of identifying progesterone related conditions as well as the importance of judiciously using a combined medical and surgical approach.

Keywords: Leiomyoma, Aglepristone, Prostaglandin, Luteoma

\section{Background}

Several reproductive conditions have been described to be induced in bitches by ovarian steroidal hormones such as mammary, vaginal and vulvar tumors, vaginal prolapse or the cystic endometrial hyperplasia-pyometra complex [1, 2]. Tumors affecting the canine vaginal vestibule or vulva are rare, accounting for $2.4-3 \%$ of all tumors occurring in the dog and being mostly benign mesenchymal tumors such as leiomyomas or fibromas [3-5]. These tumors are

\footnotetext{
* Correspondence: lluisferredolcet@gmail.com

Department of Animal Medicine, Production and Health, University of Padua, Padua, Italy
}

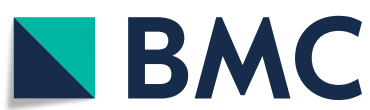

(c) The Author(s). 2020 Open Access This article is licensed under a Creative Commons Attribution 4.0 International License, which permits use, sharing, adaptation, distribution and reproduction in any medium or format, as long as you give appropriate credit to the original author(s) and the source, provide a link to the Creative Commons licence, and indicate if changes were made. The images or other third party material in this article are included in the article's Creative Commons licence, unless indicated otherwise in a credit line to the material. If material is not included in the article's Creative Commons licence and your intended use is not permitted by statutory regulation or exceeds the permitted use, you will need to obtain permission directly from the copyright holder. To view a copy of this licence, visit http://creativecommons.org/licenses/by/4.0/. The Creative Commons Public Domain Dedication waiver (http://creativecommons.org/publicdomain/zero/1.0/) applies to the data made available in this article, unless otherwise stated in a credit line to the data. muscle derived masses which do not cause metastasis in other organs [6, 7]. Ovarian tumors are reported to be uncommon in dogs [8-11]. Sex cord-stromal tumors have the ability to be hormonally active [12].

Surgical excision of vaginal masses through episiotomy has been described as the treatment of choice [13-15]. However, because of a) the old age of these patients and the risk performing extensive episiotomy and $b$ ) the fact that the growth of these masses may be stimulated by ovarian steroids, the use of steroidal hormones receptor antagonists or surgical ovariectomy have been reported 
as successful treatments [16, 17]. Aglepristone (AGLE) (Alizin ${ }^{\circ}$, Virbac) is a synthetic antiprogestogen marketed as an abortifacient in bitches in Europe and Australia and its off-label use for progesterone-related canine conditions has been reported [18]. Alfaprostol is a synthetic prostaglandin F2apha (PGF2 $\alpha$ ) compound marketed for use in food animals and reported to be able to induce luteolysis also in bitches [19].

\section{Case presentation}

A 11-year old intact Labrador Retriever bitch was referred to the Veterinary Teaching Hospital of the University of Padova (Italy) because of a vaginal mass prolapsing from the vulva (Fig. 1). The bitch had a history of regular cycling every 8 months, had never been pregnant, her vaccination and heartworm prevention programs were current and had had no other health problem until shortly after the onset of her most recent proestrus ( 1 week prior to referral) when she started to become anuric and constipated. Because of constipation, her diet was changed to a commercial fiber diet. Presence of perineal swelling, an abundant bloody and muco-purulent vaginal discharge and a mass protruding from the vulva were first noticed 3 days after onset of proestrus. On clinical exam on the day of referral (day 1) the bitch was alert and normally responsive and her clinical parameters (pulse, respiration and rectal temperature, skin and subcutis and palpable lymph nodes) were normal. Her perineal area appeared enlarged and a rounded mass was protruding from the vulvar labia, covered by pink translucent vaginal mucosa. On digital palpation the mass had a very hard consistency and it was impossible to insert the operator's finger beyond the vestibulum due to the mass occupying the entire vestibular lumen. Vaginal cytology was performed and stained with Diff Quick (RAL diagnostics, Milan, Italy) showing a 1:1 rate of intermediate and keratinized cells with abundant neutrophils and a small percentage of red blood cells.
Abdominal ultrasonography showed a normal appearance of the uterine wall and mucosa and lack of fluid in the uterine lumen; several antral follicles of $\leq 0.7 \mathrm{~cm}$ diameter were detected in both ovaries (Fig. 2a). Ultrasonography of the perineal area showed the mass to be originating from the cranial vagina and invading the vestibulum (Fig. 2b). Complete blood count revealed mild leukocytosis $\left(22.10 \times 10^{3} / \mu \mathrm{l}\right)$; biochemistry was unremarkable. Serum progesterone (P4) concentration measured with immunofluorometry (AIA 369 TOSOH, FUTURLAB s.r.l., Padova, Italia) was $4.94 \mathrm{ng} / \mathrm{mL}$ demonstrating the presence of luteal tissue. Because of the progressive increase in mass size after the onset of proestrus and considering the potential presence of $\mathrm{P} 4$ receptors within the mass [17] a $10 \mathrm{mg} / \mathrm{kg}$ dose of the P4 receptor antagonist AGLE was administered subcutaneously on day 1 and repeated the following day. Such treatment has been shown to reduce the size of a vaginal leyomioma by $50 \%$ in an older crossbreed bitch allowing for an easier surgical removal [17]. Antibiotic therapy with enrofloxacin $(5 \mathrm{mg} / \mathrm{kg})$ for 7 days was prescribed. On day 8 after presentation vaginal edema was slightly decreased in volume and the mass was not protruding from the vulva; however, it was still causing swelling of the perineum and on vaginal palpation its consistency was unchanged. The owner reported that constipation had improved starting from $48 \mathrm{~h}$ after the second AGLE injection, but the bitch was still anuric and with an abundant purulent vulvar discharge. On hematology and biochemistry the only abnormality was leukocytosis $\left(37.98 \times 10^{3} / \mu \mathrm{l}\right)$ while all other parameters (including kidney function) were normal. P4 concentrations had increased to $22.4 \mathrm{ng} / \mathrm{mL}$. On abdominal ultrasonography the reproductive system showed no change while dilatation of the urinary bladder and ureters was observed which was causing hydronephrosis. A Foley catheter was inserted into the urethra and the bladder was emptied. A $10 \mathrm{mg} / \mathrm{kg}$ AGLE dose was administered and a combination of

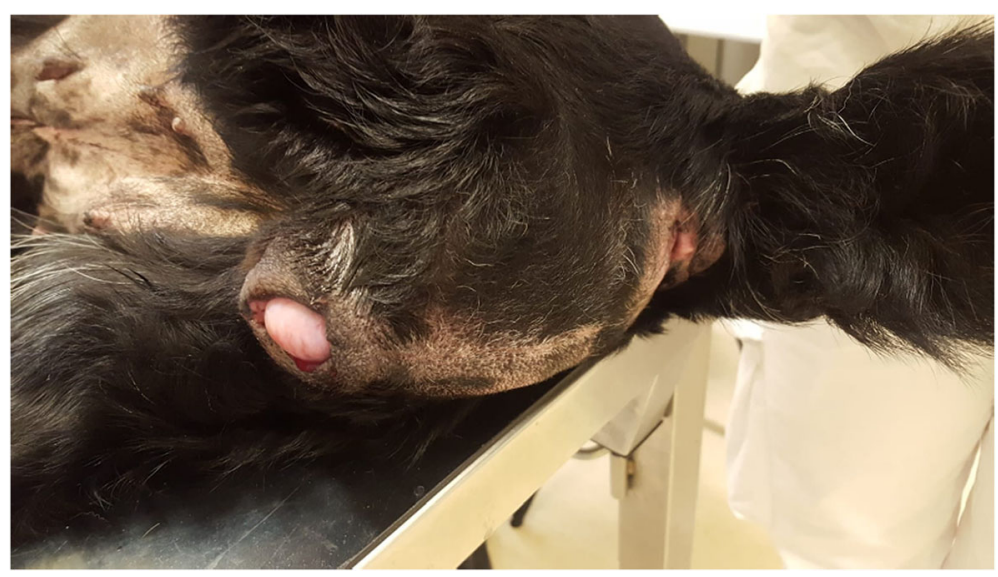

Fig. 1 Large ovoid-shaped vaginal mass prolapsing from the vulvar commissure of an 11-year old intact Labrador bitch 


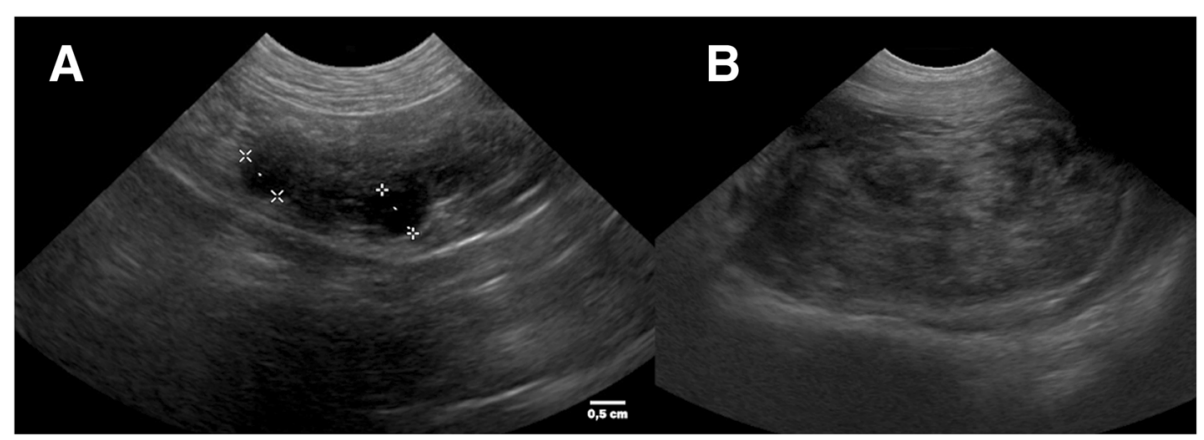

Fig. 2 a Ultrasonography of the right ovary presenting preantral follicles of $0,7 \mathrm{~cm}$. $\mathbf{b}$ Ultrasonography of the perineal area presenting the vaginal mass encapsulated in the cranial vagina

enrofloxacin and amoxicillin-clavulanic acid (5 $\mathrm{mg}$ and 15 $\mathrm{mg} / \mathrm{kg}$, respectively) twice daily was prescribed for another week to replace enrofloxacin as empiric treatment until urinary results would be available. On day 11 a total body computed tomography (CT) was performed under intravenous anaesthesia in order to evaluate size and position of the mass and determine whether other internal organs were affected. After premedication with $0.03 \mathrm{mg} / \mathrm{kg}$ acepromazine (Fatro, Italy) and $0.1 \mathrm{mg} / \mathrm{kg}$ methadone (Dechra, The Netherlands) intramuscularly, propofol 1\% (Merial, Italy) was administered using a target controlled infusion system to induce and maintain anesthesia [20]. A large, ovoid shaped, heterogeneous, moderately contrast enhancing (pre- and post-contrast enhancement $32 \pm 9$ $\mathrm{HU}$ and $63 \pm 9 \mathrm{HU}$, respectively) mass, measuring 12.72 $\mathrm{cm}$ in length, $6.52 \mathrm{~cm}$ in height and $8.33 \mathrm{~cm}$ in width, was visible on CT. The mass aroused from the vaginal wall from the middle third of the vagina and vastly protruded out from the pelvic canal and vagina. The rectum was displaced dorsally and the pelvic urethra ventrally. The urinary bladder was markedly distended reaching the cranial margin of L3. Both ureters were dilated $(0.72 \mathrm{~cm})$ and bilateral pyelectasis was evident (Fig. 3a-b). Regional lymph nodes were unremarkable. In addition to CT, an ultrasound guided transcutaneous needle biopsy was performed using a $20 \mathrm{G} \mathrm{X} 100 \mathrm{~mm}$ (ZAMAR s.r.l., Mantova, Italy). Pressure controlled mechanical ventilation and main cardiovascular and respiratory variables monitoring were guaranteed throughout both procedures. Histopathology revealed a thin outer layer of mesenchymal fibrous tissue with a cellular population represented by spindle elements, lacking defined margins with an eosinophilic cytoplasm. Histological patterns were compatible with a diagnosis of leyomioma (Fig. 4). The bitch was sent home with a urinary Foley catheter positioned in situ. On day 15 ureters and kidneys showed normal ultrasonographic patterns. Antibiotic theraphy was stopped at this time. The mass had apparently stopped growing. As P4 concentration had reached $39.5 \mathrm{ng} / \mathrm{mL}$ another $10 \mathrm{mg} / \mathrm{kg}$ dose of AGLE was administered. On day 18, P4 levels measured with immunofluorometry were $>40 \mathrm{ng} / \mathrm{mL}$. As $40 \mathrm{ng} / \mathrm{mL}$ is the upper range of the immunofluorometry system, a dilution of 1:4 was performed in order to determine real $\mathrm{P} 4$ concentration which was $124 \mathrm{ng} / \mathrm{mL}$. Due to such increased P4 secretion,

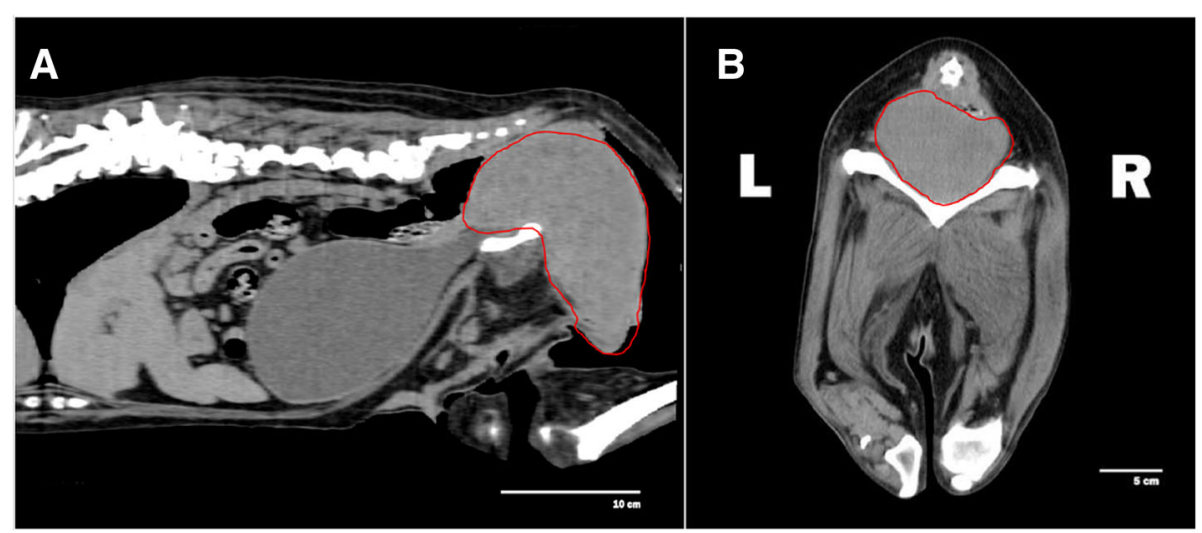

Fig. 3 a Sagital image from a computerized tomography showing the vaginal mass measuring $12.72 \mathrm{~cm}$ in length, arousing from the cranial vagina and protruding from the pelvic canal. The urinary bladder shows to be enlarged due to the urethral compression. b Transversal image from a computerized tomography showing the presence of the vaginal mass of $6.52 \mathrm{~cm}$ in height and $8.33 \mathrm{~cm}$ in width, leaning on the pelvic bones provoking urethral compression 


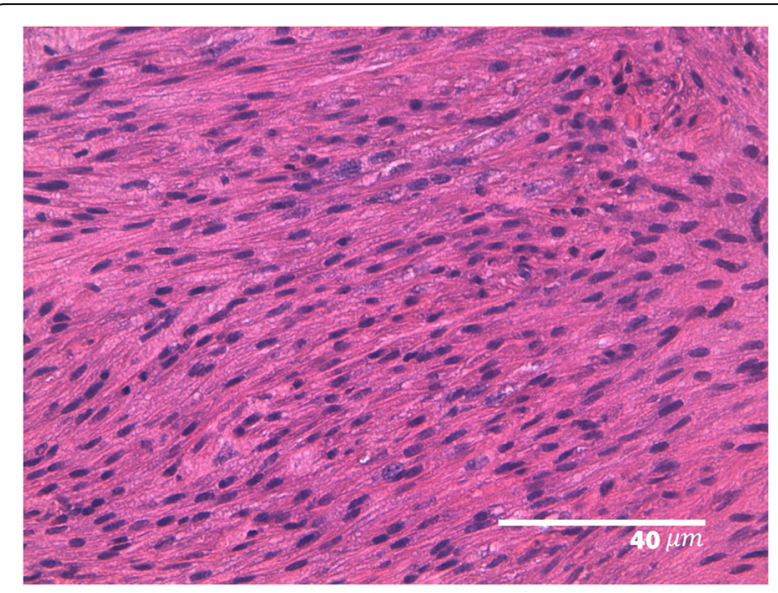

Fig. 4 Histological image from the vaginal biopsy. The image presents a thin outer layer of mesenchymal fibrous tissue with a cellular population represented by spindle elements with defined margins and an eosinophilic cytoplasm. The image is compatible with a leyomioma

an IM treatment course with $0.02 \mathrm{ng} / \mathrm{kg}$ of the synthetic PGF2 $\alpha$ alfaprostol (Gabbrostim ${ }^{\circ}$ CEVA-VETEM, Milan, Italy) was started twice daily. The Foley catheter was removed. On day 20, hydronephrosis was again observed on ultrasonography. Serum P4 was $39 \mathrm{ng} / \mathrm{mL}$ (following samples dilution 1:1). Owners were instructed on how to perform manual abdominal compression to empty the bladder at home. On day 22 urine from the bladder was collected by cystocentesis and a urinalysis and urine culture with antibiogram were performed revealing a specific weight of 1.008 and a high population of multi-resistant Klebsiella spp. sensible only to trimethoprim-sulfonamide (TMP/ SMX). The bitch received another $10 \mathrm{mg} / \mathrm{kg}$ dose AGLE and was started on an oral twice daily treatment with TMP/SMX ( $4 \mathrm{mg} / \mathrm{kg}$ and $20 \mathrm{mg} / \mathrm{kg}$, respectively).

On day 29 the bitch was clinically normal but the mass was still present without any relevant change in size. Serum P4 was $61 \mathrm{ng} / \mathrm{mL}$ (following 1:1 dilution) in spite of a 10-day twice daily treatment course with PGF2 $\alpha$. Another $10 \mathrm{mg} / \mathrm{kg}$ dose AGLE was administered. Because of the failure of luteolysis and fearing a P4-led progressive increase of the vaginal mass causing irreversible renal damage, ovariohysterectomy (OHE) was planned. On day 36 the bitch was sedated and anesthetized using the same protocol adopted for the CT scan on day 11. OHE was uneventful and the bitch recovered well. On macroscopical assessment a total of 23 corpora lutea were counted, 11 on the left ovary and 12 on the right ovary (Fig. 5a-b); the uterine body and uterine horns did not reveal any alterations. Following fixation in $4 \%$ paraformaldehyde, histology of the uterus revealed a superficial multifocal endometrial hemorrhage with no other alterations; the right ovary showed the presence of multiple normal corpora lutea; the left ovary showed multiple corpora lutea and a delimitated, non-capsular and non-infiltrative nodular lesion of $0,3 \mathrm{~cm}$ diameter composed of elements arranged in rugs and separated by thin fibrovascular septa. The cells appeared polygonal and occasionally palisade with moderate and abundant cytoplasm variably vacuolized with round and central nucleus; a light degree of atypia without mitosis was present. Such histological patterns were compatible with a diagnosis of luteoma (Fig. 6). Once diagnosis of the ovarian tumor was done, serum samples were used for testosterone detection (due to the fact that human luteomas are androgen secretory in $30 \%$ of the cases [21]) revealing testosterone levels of $<0.2 \mathrm{ng} / \mathrm{mL}$ in every sample performed. On day 45 the bitch was clinically normal, very active and was now able to urinate spontaneously. Serum P4 levels were not detectable and the mass showed to be significantly reduced but still palpable in vagina. No bacterial growth could be observed on a cystocentesis urine sample. On day 56 the bitch returned for a recheck. On physical exam her clinical parameters were normal but developed skin lesions on her chin over the last 3-4 days showing a deep pyoderma with furunculosis. Aerobic and anaerobic bacteriology was performed from vagina, urine and skin of the chin. Urine culture and swabs from vagina were negative while skin bacteriology revealed the presence of a coagulase-positive Staphylococcus spp. and a Klebsiella spp. both sensible to amoxicilinclavulanic acid. The dog was treated with a combination of amoxicillin-clavulanic acid at the dose of $20 \mathrm{mg} / \mathrm{Kg}$ twice daily for 14 days. On day 125 (3 months post-OHE) another CT was performed to assess the vaginal mass whose volume was markedly reduced, measuring $9.5 \mathrm{~cm}$ in length, $2.7 \mathrm{~cm}$ in height and $3.6 \mathrm{~cm}$ in width. The urinary bladder was empty and the pelvic urethra and both ureters were within normal limits. No pyelectasis was evident (Fig. 7a-b).

\section{Discussion and conclusion}

History, clinical findings, endocrine tests and vaginal histology of this case are all consistent with a diagnosis of vaginal leiomyoma sensitive to steroid hormones. Because of the old age of the dog and the size and position of her vaginal mass requiring extensive episiotomy, surgical removal of the mass was not our first choice. AGLE has been used successfully to reduce the size of a vaginal fibroma in an adult bitch [17]. Therefore, a total of six $10 \mathrm{mg} / \mathrm{kg}$ AGLE injections were administered to this bitch. Serum P4 continued to increase during AGLE treatment. Such an increase was unexpected. AGLE is known to leave serum P4 concentrations unaltered [22] unless treatment occurs during mid-diestrus at which time luteolysis is reported to occur [23]; This bitch was at the beginning of her diestrus when she received her first AGLE administration, therefore we did not expect luteolysis to occur immediately; instead she showed a marked 


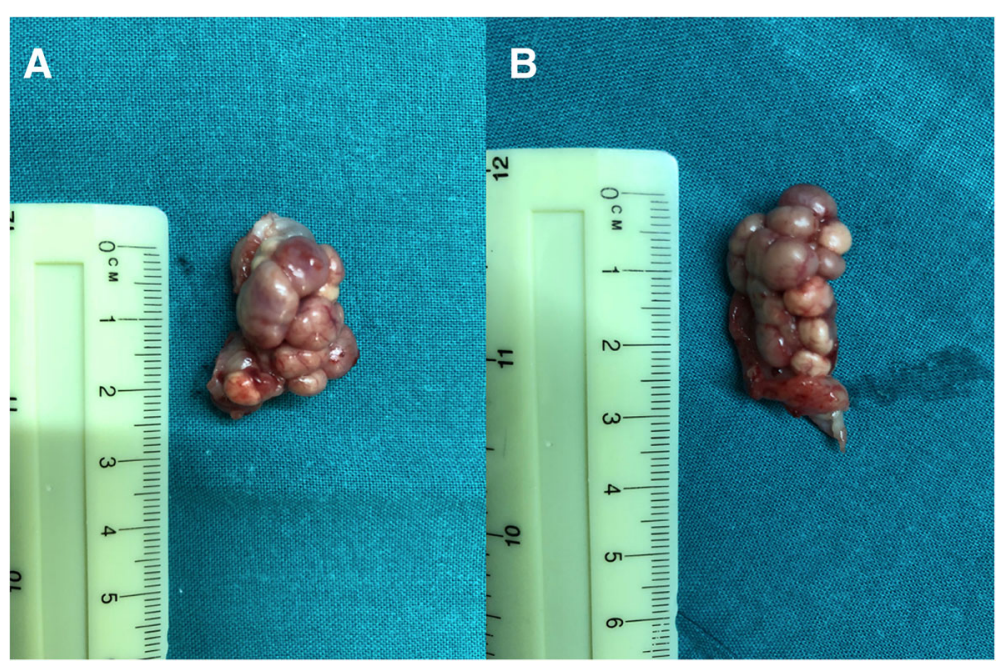

Fig. 5 a Macroscopical image of the left ovary presenting 11 corpora lutea. b Macroscopic image of the right ovary presenting 12 corpora lutea

serum P4 increase following treatment with AGLE, something which has never been reported. We feared that the $10 \mathrm{mg} / \mathrm{kg}$ AGLE dose might be insufficient to deal with the unusually high serum P4 concentrations of this bitch. Normal serum P4 concentration during the canine diestrus have been reported to range between 10 and $30 \mathrm{ng} /$ $\mathrm{mL}$ [24-26]. The decision to start a medical treatment with the synthetic PGF2 $\alpha$ alfaprostol and subsequently to opt for OHE was driven by a) considerations on the importance of blocking the action of endogenous $\mathrm{P} 4$ to help management of these conditions [17], b) concern about the unusually high serum P4 concentrations despite

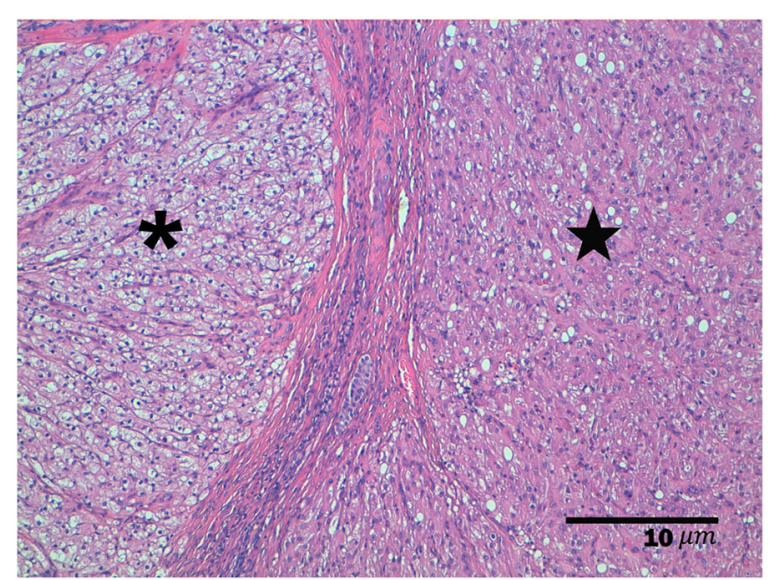

Fig. 6 Histological image of the left ovary presenting a normal corpora lutea (astherisc) and a non-encapsulated and non-infiltrative nodular lesion composed of elements arranged in rugs and separated by thin fibrovascular septa (star). The cells of the nodular lesion are polygonal and occasionally as palisade with moderate and abundant cytoplasm variably vacuolized with round and central nucleus. The cells present a light degree of atypia without mitosis. A diagnosis of luteoma is compatible treatment, c) fear that increasing serum P4 concentrations might cause worsening of urinary conditions and d) no signs of luteolysis were observed at ovarian level during ultrasound controls. The fact that 12 weeks after OHE the mass was reduced by $86.7 \%$ is an indirect confirmation that progesterone played a role in the development of this condition. The ovarian luteoma present on the left ovary was likely responsible for the failure of AGLE+ PGF $2 \alpha$ treatment to cause luteolysis, probably due to the unusual high concentrations of serum $\mathrm{P} 4$ secreted by the ovary. Ovariohysterectomy is known to reduce the size of hormone-sensitive vaginal masses $[16,17]$. Surgery is certainly the treatment of choice in these cases, however the surgical approach was not considered initially because of the old age of this bitch and the owner's concern about its related risks. In addition, the reduced vaginal mass was left in situ because its presence did not interfere to the bitch to continue with a healthy life.

Because of the amount of bladder distension, a complicated cystitis with bladder wall invasion was suspected. Therefore, the initial choice of an antibiotic treatment for this bitch was enrofloxacin due to the ease and speed with which this drug achieves tissue penetration [27, 28]. When urinalysis was performed at day 8 of referral, the bitch was hyposthenuric (urinary specific weight of 1008) and no bacteria were present in the sediment. However, it has been described that low urinary specific weights might create a false negative bacteriuria in the sediment [29]. The reason for adding amoxicillin-clavulanic acid a week later was to broaden the spectrum of coverage because of the increasing leukocytosis and the suspicious false negative bacterial cystitis. The use of fluoroquinolones and amoxicillin-acid clavulanic should be guided by culture and sensitivity results. Unfortunately, this was not done. A multi-resistant Klebsiella was found growing in urine 


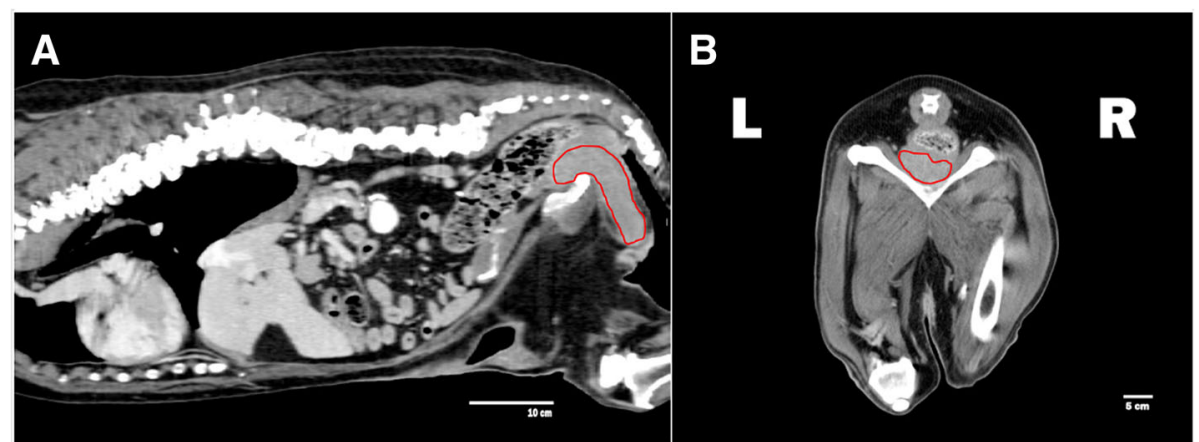

Fig. 7 a Sagital image from a computerized tomography showing the reduction of the vaginal mass $(9463 \mathrm{~cm}$ length) on the pelvic canal. The urinary bladder shows to be empty. $\mathbf{b}$ Transversal image from a computerized tomography showing the presence of the reduced vaginal mass of $2,7 \mathrm{~cm}$ height and $3,6 \mathrm{~cm}$ width. Dorsally to the mass rectum can be observed

culture on day 22: such a bacteria was certainly present in the bladder of this bitch already upon presentation although it is unknown whether or not it was already multiresistant or if its multi-resistant status developed following the combined use of enrofloxacin and amoxicillinclavulanic acid. As $E$. coli is frequently identified as a cause of cystitis and because of the close proximity of the prolapsed vaginal tissue with the anus, the occurrence of a complicated multibacterial ascending cystitis with $E$. coli and Klebsiella spp. upon presentation cannot be ruled out as the combined enrofloxacin and amoxicillin-clavulanic acid antibiotherapy may have eliminated the E.coli population.

The size of the vaginal mass of this bitch did not decrease during treatment unlike what happened in the case of Rollon et al., (2007) who observed a 30\% reduction of a $9 \times 5 \mathrm{~cm}$ vaginal mass after 4 weeks of AGLE treatment. The larger size of the vaginal mass of this case $(12.7 \times$ $6.5 \times 8.3 \mathrm{~cm}$ ) plus the high serum P4 concentration may account for failure to cause reduction in mass size despite treatment. Following surgery, the vaginal mass decreased fairly rapidly with the bitch being capable of urinating spontaneously already 7 days following surgery. Such a rapid improvement (faster than what reported by Rollon et al., 2007) underlines the difference in the clinical effect on the target organ when comparing the use of $\mathrm{P} 4$ receptor blockers to the surgical removal of $\mathrm{P} 4$ production.

Luteomas are considered sex cord-stromal tumors potentially able to secrete steroid hormones $[3,4,12]$. Sex cord-stromal tumors seem to be the most commonly reported ovarian tumors in the female with the least and the most common species being sows and queens, respectively [30]. These tumors seem to be derived from the luteal cells of ovarian stroma $[4,9]$. Human luteomas are rare benign tumors occurring either in pregnancy or after menopause [31]. Human gestational luteomas are spontaneously regressing tumors which may cause virilization of female fetuses due to their androgen secretion [21, 32]. Only two cases of canine ovarian luteoma have been described [12, 33] with both cases developing from ovarian remnants in spayed bitches. The histological pattern of the ovary of this case (polyhedral cells with abundant vesicular cytoplasm) and the unusual secretion of $\mathrm{P} 4$ was compatible with an ovarian sex-cord tumor resembling luteoma.

To our knowledge this is the first report about a vaginal leiomyoma concomitant with an ovarian luteoma in a bitch with uncommon secretion of P4. This case demonstrates the importance of identifying and characterizing P4 related conditions as well as the importance of judiciously using a combined medical and surgical approach. OHE should always be considered when dealing with small animal reproductive conditions occurring in diestrus. This is particularly true when dealing with older patients in which an elective, uncomplicated OHE may be better than a longer and more invasive surgery. A medical approach using a P4-receptor blocker and/or a luteolytic agent may be indicated for patients who are poor surgical candidates.

\section{Abbreviations}

AGLE: Aglepristone; PGF2a: Prostaglandin F2 alpha; P4: Progesterone; CT: Computed tomography; TMP/SMX: Trimethropim-sulfonamide; OHE: Ovariohysterectomy

\section{Acknowledgements}

The authors would like to thank to the support of laboratory technicians.

\section{Authors' contributions}

LFD and SR followed the case, took the decisions of medical or surgical stratergies, draft the manuscript and revised. TB = followed the case from the diagnostic imaging point of view and interpretation of images. $L C=$ Analysis and interpretation of histopatholocical data. RDM and MB = Followed the urinary and dermatologic complications of the case. $A C=$ supported the case when anesthesia was required. $M S$ and $A M=$ Supported the surgical procedure. All authors read and approved the final manuscript.

Funding

Not applicable. 


\section{Availability of data and materials}

The datasets used and/or analyzed during the resolution of the case are available from the corresponding author on reasonable request.

\section{Ethics approval and consent to participate}

Not applicable.

\section{Consent for publication}

The owner of the bitch gave written consent for publication.

\section{Competing interests}

The authors declare that they have no competing interests.

Received: 10 September 2019 Accepted: 3 August 2020

Published online: 10 August 2020

\section{References}

1. Alexander JE, Lennox WJ. Vaginal prolapse in a bitch. Can Vet J. 1961;2(11): 428-30.

2. Dow C. The cystic hyperplasia-pyometra complex in the bitch. J Comp Pathol. 1959;69:237-50

3. Thacher C, Bradley RL. Vulvar and vaginal tumors in the dog: a retrospective study. J Am Vet Med Assoc. 1983;183(6):690-2.

4. McEntee MC. Reproductive oncology. Clin Tech Small Anim Pract. 2002 17(3):133-49.

5. Brodey RS, Roszel JF. Neoplasms of the canine uterus, vagina, and vulva: a clinicopathologic survey of 90 cases. J Am Vet Med Assoc. 1967;151(10): 1294-307.

6. Klein MK. Tumors of the female reproductive system. In: Wihtrow SJ Macewem EG, editors. Small animal clinical oncology. Philadelphia: Saunders; 2007. p. 610-618.

7. Devereaux KA, Schoolmeester JK. Smooth muscle tumors of the female genital tract. Surg Pathol Clin. 2019;12(2):397-455.

8. Saba CF, Lawrence JA. Tumors of the female reproductive system. In: Withrow and MacEwen's small animal clinical oncology: Elsevier. Philadelphia: Saunders; 2013. p. 532-7.

9. Nielsen SW, Misdorp W, McEntee K. Tumours of the ovary. Bull World Health Organ. 1976;53(2-3):203-15.

10. Mcentee K, Nielsen SW. Tumours of the female genital tract. Bull World Health Organ. 1976;53:217.

11. Patnaik AK, Greenlee PG. Canine ovarian neoplasms: a Clinicopathologic study of 71 cases, including histology of 12 Granulosa cell tumors. Vet Pathol. 1987;24(6):509-14.

12. Yamini B, VanDenBrink PL, Refsal KR. Ovarian steroid cell tumor resembling Luteoma associated with Hyperadrenocorticism (Cushing's disease) in a dog. Vet Pathol. 1997:34(1):57-60.

13. Kang TB, Holmberg DL. Vaginal leiomyoma in a dog. Can Vet J. 1983;24(8): 258-60.

14. Nelissen P, White RAS. Subtotal Vaginectomy for Management of Extensive Vaginal Disease in 11 dogs. Vet Surg. 2012;41(4):495-500.

15. Manothaiudom K, Johnston SD. Clinical approach to vaginal/vestibular masses in the bitch. Vet Clin North Am Small Anim Pract. 1991;21(3):509-21.

16. Sathya S, Linn K. Regression of a vaginal leiomyoma after Ovariohysterectomy in a dog: a case report. J Am Anim Hosp Assoc. 2014; 50(6):424-8.

17. Rollón E, Millán Y. de las Mulas JM. Effects of aglepristone, a progesterone receptor antagonist, in a dog with a vaginal fibroma. J Small Anim Pract. 2007:49(1):41-3.

18. Gogny A, Fiéni F. Aglepristone: a review on its clinical use in animals. Theriogenology. 2016;85(4):555-66.

19. Onclin K, Silva LDM, Verstegen JP. Termination of unwanted pregnancy in dogs with the dopamine agonist, cabergoline, in combination with a synthetic analog of PGF2alpha, either cloprostenol or alphaprostol. Theriogenology. 1995:43:813-22.

20. Cattai A, Bizzotto R, Cagnardi P, Di Cesare F, Franci P. A pharmacokinetic model optimized by covariates for propofol target-controlled infusion in dogs. Vet Anaesth Analg. 2019;46:568-78.

21. Masarie K, Katz V , Balderston K. Pregnancy luteomas: clinical presentations and management strategies. Obstet Gynecol Survey. 2010;65:575-82.
22. Galac S, Kooistra H, Dieleman S, Cestnik V, Okkens A. Effects of aglépristone, a progesterone receptor antagonist, administered during the early luteal phase in non-pregnant bitches. Theriogenology. 2004;62(3-4):494-500.

23. Polisca A, Scotti L, Orlandi R, Brecchia G, Maranesi M, Zerani M, et al. Aglepristone (RU534) administration to non-pregnant bitches in the mid-luteal phase induces early luteal regression. Theriogenology. 2010;74(4):672-81.

24. Ververidis HN, Boscos CM, Stefanakis A, Saratsis P, Stamou Al, Krambovitis E. Serum estradiol-17 $\beta$, progesterone and respective uterine cytosol receptor concentrations in bitches with spontaneous pyometra. Theriogenology. 2004;62(3-4):614-23.

25. Bigliardi E, Bresciani C, Callegari D, Di lanni F, Morini G, Parmigiani E, et al. Use of aglepristone for the treatment of P4 induced insulin resistance in dogs. J Vet Sci. 2014;15(2):267-71.

26. Chakraborty PK. Reproductive hormone concentrations during estrus, pregnancy, and pseudopregnancy in the Labrador bitch. Theriogenology. 1987;27(6):827-40

27. Weese JS, Blondeau J, Boothe D, Guardabassi LG, Gumley N, Papich M, et al. International Society for Companion Animal Infectious Diseases (ISCAID) guidelines for the diagnosis and management of bacterial urinary tract infections in dogs and cats. Vet J. 2019;247:8-25.

28. Jorgensen JH, Hindler JF, Barth Reller L, Weinstein MP. New consensus guidelines from the clinical and laboratory stardards institure for antimicrobial susceptibility testing of infrequently isolated or fastidious bacteria. Clin Infect Dis. 2007:44(2):280-6.

29. Barsanti JA, Finco DR. Laboratory findings in urinary tract infections. Vet Clin North Am Small Anim Pract. 1980;9(4):729-48.

30. MacLachlan NJ. Ovarian disorders in domestic animals. Environ Health Perspect. 1987:73:27-33.

31. Hayes MC, Scully RE. Stromal luteoma of the ovary: a clinicopathological analysis of 25 cases. Int J Gynecol Pathol. 1987;6(4):313-21.

32. Wadzinski TL, Altowaireb Y, Gupta R, Conroy R, Shoukri K. Luteoma of pregnancy associated with nearly complete virilization of genetically female twins. Endocr Pract. 2014:20(2):e18-23.

33. Ichimura R, Shibutani M, Mizukami S, Suzuki T, Shimada Y, Mitsumori K. A case report of an uncommon sex-cord stromal tumor consisted of luteal and sertoli cells in a spayed bitch. J Vet Med Sci. 2010;72(2):229-34.

\section{Publisher's Note}

Springer Nature remains neutral with regard to jurisdictional claims in published maps and institutional affiliations.

Ready to submit your research? Choose BMC and benefit from

- fast, convenient online submission

- thorough peer review by experienced researchers in your field

- rapid publication on acceptance

- support for research data, including large and complex data types

- gold Open Access which fosters wider collaboration and increased citations

- maximum visibility for your research: over $100 \mathrm{M}$ website views per year

At BMC, research is always in progress.

Learn more biomedcentral.com/submissions 